\title{
Balçova'da 30 yaş ve üzeri diyabetlilerde tedavi alma ve kan glukoz düzeyinin kontrol altına alınma durumu
}

\author{
Kevser Tarı Selçuka, Melih Kaan Sözmenb, Belgin Ünalc
}

\author{
a Öğr. Gör. Dr., Bandırma Sağlık Yüksekokulu Hemșirelik Bölümü, Balıkesir \\ b Yrd. Doç. Dr., Katip Çelebi Üniversitesi Tıp Fakültesi Halk Sağlı̆̆g Anabilim Dalı, İzmir \\ c Prof. Dr., Dokuz Eylül Üniversitesi Tıp Fakültesi Halk Sağlığı Anabilim Dalı, İzmir \\ Geliş tarihi: 28.03.2014, Kabul tarihi: 19.11.2014
}

\section{Özet}

Amaç: Bu kesitsel araştırmada Balçova'da 30 yaş ve üzeri diyabetlilerde tedavi alma, tedavi alanlarda kan glukoz düzeyi, BKİ, kan basıncı ve lipidlerin kontrol altına alınma durumunun saptanması, tedavi alma ve kan glukoz düzeyinin kontrol altına alınma durumunun bazı sosyodemografik özelliklerle ilişkisinin incelenmesi amaçlanmaktadır. Yöntem: Araştırmada Balçova'nın Kalbi projesinin durum saptama çalışmasına katılan 30 yaş ve üzeri 1.643 diyabetlinin verisi değerlendirilmiştir. Diyabet tanısında AKŞ ölçümü yapılmış, değerlendirmede ADA 2011 yılı tanı kriterleri kullanılmıştır. Çözümlemede tanımlayıcı istatistikler, ki kare testi, lojistik regresyon analizinden yararlanılmıştır. Araştırma Dokuz Eylül Üniversitesi Bilimsel Araștırma Projeleri ve Balçova Belediyesi tarafından desteklenmiştir (Proje no: 2007161). Bulgular: Diyabetlilerin \%75.4'ü tedavi almaktadır, tedavi alanların \%32.6'sında kan glukoz düzeyi, \%21.8'inde kan basıncı, \%9.4'ünde BKİ, \%34.7'sinde LDL, \%45.2'sinde HDL, \%52.6'sında trigliserit düzeyi kontrol altındadır. Lojistik regresyon modeline göre diyabet tedavisi alma durumu 70 ve üzeri yaş grubunda [OR=1.76, \%95.0 GA:1.14-2.72], sosyal güvenceye sahip olanlarda [OR=2.21, \%95.0 GA:1.39-3.52] ve eşlik eden kronik hastalığı olanlarda [OR=2.24, \%95.0 GA:1.74-2.89] anlamlı düzeyde yüksektir. Diyabet tedavisi alanlarda lojistik regresyon modeline göre kan glukoz düzeyinin kontrol altına alınma durumu eşlik eden kronik hastalığı olanlarda [OR=1.49, \%95.0 GA:1.12-1.99)] anlamlı düzeyde yüksektir. Sonuç: Diyabetli her dört kişiden biri tedavi almamaktadır, her üç kişiden sadece birinin kan glukoz düzeyi kontrol altındadır. BKİ, kan basıncı ve lipidlerin kontrol altına alınma oranı istenen düzeyde değildir. Diyabetlilerde düzenli tedavi konusunda farkındalığın arttırılması, izlemlerin nitelikli biçimde yapılması sağlanmalıdır.

Anahtar Kelimeler: Diyabet, diyabet tedavisi, kan glukoz düzeyi.

Sorumlu Yazar: Kevser Tarı Selçuk, Bandırma Sağlık Yüksekokulu Hemşirelik Bölümü, Balıkesir. Tel: +90 506 1336992, E mail: kevser tari@hotmail.com 


\title{
Treatment and blood glucose level control of diabetes patients aged 30 and above in Balcova
}

\begin{abstract}
Objective: This cross-sectional study aims to evaluate the treatment uptake and control rates of blood glucose, BMI, blood pressure, lipid levels in diabetes patients aged 30 and above in Balcova Heart Study. The association between treatment and blood glucose level control and socio-demographic characteristics will also be evaluated. Methods: The study included data from 1.643 diabetes patients aged 30 and above who participated in the baseline survey of Balcova's Heart Project. Fasting blood glucose test was carried out for diagnosis of diabetes, and ADA 2011 diagnosis criteria were employed for the overall assessment. Descriptive statistics, chi-square, logistic regression analysis were used. The study was supported by Dokuz Eylul University Scientific Research Projects and Balcova Municipality. Results: Of all patients, 75.4\% are receiving treatment, $32.6 \%$ of treated patients have blood glucose level, $21.8 \%$ have blood pressure, 9.4\% have BMI, 34.7\% have LDL, $45.2 \%$ have HDL, and 52.6\% have triglyceride levels under control. According to logistic regression model, diabetes treatment is significantly high for 70 and above age group [OR=1.76, \%95.0 CI:1.14-2.72]; for patients with social security[OR=2.21, \%95.0 CI:1.39-3.52]; and for patients with coexisting chronic diseases[OR=2.24, \%95.0 CI:1.74-2.89]. According to logistic regression model, blood glucose level control of treated patients is significantly high for patients with coexisting chronic diseases [OR=1.49, \%95.0 GA:1.12-1.99)]. Conclusions: One fourth of diabetes patients are not receiving treatment, and only one third of patients have blood glucose level under control. BMI, blood pressure, lipid control rates are below desired levels. Awareness of diabetes patient on importance of continuous follow-up should be raised, and quality follow-up should be improved.
\end{abstract}

Key Words: Diabetes, diabetes treatment, blood glucose level.

\section{Giriş}

Diyabet, nüfusun yaşlanması, obezite ve fiziksel inaktivitenin artmasına bağlı olarak sıklı̆̆ tüm dünyada giderek artan küresel bir halk sağlığı sorunudur. ${ }^{1}$ Uluslararası Diyabet Federasyonu (IDF) tarafindan yapılan projeksiyonlarda 2013 yılında Avrupa'da 20-79 yaş grubunda \%8.5 olan diyabet prevalansının 2035 yılında \%10.3'e ulaşacağı öngörülmektedir. ${ }^{2}$ Türkiye'de diyabet sıklığının belirlenmesine yönelik yürütülen çalışmalarda son on iki yılda diyabet sıklığındaki artışın yaklaşık \%90'a ulaşmış olduğunun belirtilmesi diyabetin Türkiye'de de dünyadaki duruma paralel olarak önemli bir halk sağlığı sorunu olduğunu göstermektedir.3,4
Diyabet prematüre ölüm, kardiyovasküler hastalık, retinopati, nefropati ve nontravmatik amputasyon gibi makrovasküler komplikasyon riskinde artışla ilișkili, ilerleyici bir hastalıktır.5,6 Diyabetli bireylerde kan glukoz düzeyinin yüksek seyretmesi diyabetin mikro ve makro komplikasyonlarının ortaya çlkmasına ve ilerlemesine yol açmaktadır. ${ }^{7}$ Diyabet tedavisinin temel amaçlarından biri kan glukoz düzeyi kontrolünü sağlamak; bu sayede ortaya çlkacak mikro ve makro komplikasyonları önlemek ya da ilerlemesini durdurmaktır. ${ }^{8}$

Kardiyovasküler hastalıklar diyabetlilerde mortalitenin başlıca nedenlerindendir ve bu hastalıklar 
diyabetlilerde morbiditeye katkı sağladıkları gibi, diyabet tedavisinin doğrudan ve dolaylı maliyetlerine de önemli yük getirmektedir. Yapılan çalışmalarda kardiyovasküler risk faktörlerinin azaltılması ile kardiyovasküler hastalıkların önlenebileceği veya ilerlemesinin yavaşlatılabileceği gösterilmiştir. ${ }^{9}$ Obezite tip 2 diyabet için değiştirilebilir temel bir risk faktörüdür. Obezite aynı zamanda kardiyovasküler ve mikrovasküler hastalıklar için yüksek risk taşıyan diyabetli bireylerde kan glukoz düzeyi, kan basıncı ve kolesterol düzeylerinin kontrol altına alınmasının önüne geçen bir durumdur.10 Bir diğer kardiyovasküler risk faktörü olan hipertansiyon yaş, irk ve obeziteye bağlı olarak diyabetli bireylerin yaklaşık \%2060'ını etkilemektedir. Tip 2 diyabetli hastalarda lipid düzeylerindeki bozukluklar ise kardiyovasküler hastalık oranlarının artışına katkıda bulunan kardiyovasküler risk faktörlerindendir. Lipid yönetiminde LDL (Low Density Lipoprotein) kolesterol ve trigliserit seviyesinin düşürülmesi ve HDL (High Density Lipoprotein) kolesterol seviyesinin arttırılması amaçlanmaktadır. $\mathrm{Bu}$ sayede diyabetli bireylerde mortalite ve makrovasküler hastalık sıklıklarında azalma sağlanabilmektedir. 9

Diyabetlilerde kan glukoz düzeyinin kontrolü komplikasyon gelişimini önlemekte, yaşam kalitesini artırarak yaşam süresini uzatmaktadır.11

Türkiye'de diyabetlilerin tedavi alma durumu ve diyabetlilerde kan glukoz düzeyi kontrolüne ilişkin yürütülen araştırmalar sinırlı sayıdadır ve bu araştırmalarda diyabetlilerin büyük çoğunluğunun tedavi aldığı belirtilmektedir. ${ }^{11-15}$

Diyabetlilerde kan glukoz kontrolüne ilişkin yürütülen araştırmalarda ise kontrol oranı için farklı tanı testlerinin kullanıldığı ve kontrol oranının yaklaşık \%20-40 arasında değiștiği, sonuç olarak istenilen düzeyde olmadığı bildirilmektedir.4,11-14,16,17

$\mathrm{Bu}$ araştırmada Balçova'da yaşayan 30 yaş ve üzeri grupta, diyabet hastalığı olduğu bilinen bireylerde tedavi alma durumunun saptanması ve halen tedavi alanlarda kan glukoz düzeyi, Beden Kütle İndeksi (BKI), kan basıncı ve lipid düzeylerinin kontrol altına alınma durumlarının incelenmesi; tedavi alma ve kan glukoz düzeyinin kontrol altına alınma durumlarının bazı sosyodemografik özelliklerle ilişkisinin irdelenmesi amaçlanmıştır.

\section{Gereç ve Yöntem}

Bu kesitsel tipteki araştırmada İzmir ili Balçova ilçesinde yürütülen Balçova'nın Kalbi projesinin (BAK) 2007-2008 ylları arasında gerçekleştirilen durum saptama aşamasının verileri değerlendirilmiștir. Araştırma için özel bir örnek büyüklüğü hesaplanmamış, BAK Projesinin durum saptama çalışmasına katılan, kan örneği alınan, 30 yaş ve üzeri 12.915 kişiden diyabetli olduğu belirlenen toplam 1.643 kişiye ait veriler ikincil olarak değerlendirilmiștir. ${ }^{18}$

Araştırmanın bağımlı değiş̧kenleri diyabetlilerin tedavi alma durumu ve diyabet tedavisi alan bireylerde kan glukoz düzeyinin kontrol altına alınma durumudur. Araştırmada, Amerikan Diyabet Birliği'nin (ADA) 2011 yılı tanı kriterlerine göre en az sekiz saatlik açlığı takiben yapılan ölçümde $126 \mathrm{mg} / \mathrm{dl}$ ve üzerinde plazma kan glukoz düzeyine sahip olan veya daha önce bir hekim tarafından diyabet tanısı aldığını ya da antidiyabetik ilaç kullandığını belirten bireyler "diyabetli" olarak tanımlanmıştır. ${ }^{19}$

Antidiyabetik ilaç kullanımı "tedavi alma” olarak tanımlanmıştır. Araştırma kapsaminda diyabet tedavisi alanlarda IDF önerilerine göre Açlık Kan Şekerinin (AKŞ) $110 \mathrm{mg} / \mathrm{dl}$ 'nin altında olma durumu "kan glukoz düzeyinin kontrol altına alınma durumu" olarak tanımlanmıștır. ${ }^{20}$

Yaş, cinsiyet, öğrenim durumu, medeni durum, algilanan ekonomik durum, sosyal güvence varlığl, sigara içme durumu ve eşlik eden kronik hastalık varlığı (koroner arter hastalığl, kanser, 
hipertansiyon ve stroke) bu araștırmanın bağımsız değişkenleridir. Araştırma kapsamında BKİ'nin değerlendirilmesinde Dünya Sağlı Örgütü'nün (DSÖ) sinıflandırması esas alınmış, bu sinıflandırmaya göre $30.00 \mathrm{~kg} / \mathrm{m}^{2}$ ve üzerinde BKİye sahip olma "obezite" olarak tanımlanmıştır. DSÖ'nün sinıflandırmasına göre BKİ'nin $25.00 \mathrm{~kg} / \mathrm{m}^{2}$ 'nin altında olması diyabetli bireylerde "hedef değer" olarak tanımlanmıştır. ${ }^{21}$

\section{Kan}

basincınin

değerlendirilmesinde, Yüksek Kan

Basıncinın Önlenmesi, Saptanması, Değerlendirilmesi ve Tedavisi İçin Yedinci Ortak Ulusal Komite (JNC 7) Raporunda belirtilen sınıflandırma kullanılmıştır. $\mathrm{Bu}$ sinıflandirmaya göre $120-139 \mathrm{~mm} / \mathrm{Hg}$ sistolik, $80-89 \mathrm{~mm} / \mathrm{Hg}$ diastolik kan basıncına sahip olma "prehipertansiyon", $140 \mathrm{~mm} / \mathrm{Hg}$ ve üzeri sistolik, $90 \mathrm{mmm} / \mathrm{Hg}$ ve üzeri diastolik kan basıncına sahip olma "hipertansiyon" olarak tanımlanmıştır. ${ }^{22}$

Kan basıncı kontrolünde ADA önerisi üzerine diyabetli bireylerde 130/80mm/Hg'dan düşük kan basıncl "hedef değer" olarak tanımlanmıştır. ${ }^{23}$

Kan lipid düzeylerinin sınıflandırılmasında Yetișkinlerde Yüksek Kolesterolün Tanısı, Değerlendirilmesi ve Tedavisine Yönelik 2002 Yllı Ulusal Kolesterol Eğitim Programı Üçüncü Raporunda (NCEP-ATP III) belirtilen sınıflandırmadan yararlanılmıștır. ${ }^{24}$

Diyabetli bireylerde ADA önerileri doğrultusunda LDL kolesterolün $100 \mathrm{mg} / \mathrm{dl}$ 'nin altında, HDL kolesterolün erkeklerde $\quad 40 \mathrm{mg} / \mathrm{dl}$ 'nin, kadınlarda $50 \mathrm{mg} / \mathrm{dl}$ "nin üzerinde, trigliserit düzeyinin ise $150 \mathrm{mg} / \mathrm{dl}$ 'nin altında olması ise ilgili lipid değerlerinin "kontrol altında olması" şeklinde tanımlanmıştır. ${ }^{25}$

Araştırmacılar tarafından geliştirilen anket formu eğitimli anketörler aracılığıyla bireylerin adreslerinde yüz yüze görüşme yöntemiyle uygulanmış, ardından bireyler en az sekiz saat aç kalmış olmak koşuluyla kan alma işlemi ve ölçümler için randevu verilerek Balçova Belediyesine ait en yakın semt evine davet edilmiştir. Semt evlerinde araştırma hakkında eğitilmiş sağlık personeli ve araştırmacılar tarafından ölçümler yapılmış, kanlar alınmış ve alınan kanlar Dokuz Eylül Üniversitesi Merkez Laboratuarında incelenmiştir. Araştırmanın bütçesi Dokuz Eylül Üniversitesi Bilimsel Araştırma Projeleri Birimi (BAP) ve Balçova Belediyesi tarafından desteklenmiştir (Proje no: 2007161).

Veri çözümlemede tanımlayıcı istatistikler ki kare testi ve lojistik regresyon analizinden yararlanılmıştır. Diyabet tedavisi alma durumunu öngören bir model oluşturmak amaciyla tek değişkenli analizlerde diyabet tedavisi alma durumuyla anlamlı ilişskisi bulunan yaş, cinsiyet, öğrenim durumu, sosyal güvence varlığı, sigara içme durumu ve eşlik eden kronik hastalık varlığı değişkenlerinin alındığı geriye doğru eleme yöntemi ile lojistik regresyon modeli oluşturulmuştur. Tek değişkenli analizlerde diyabet tedavisi alma durumuyla anlamlı ilişkisi bulunan medeni durum değişkeninin yaş ile korele olduğu düşünüldüğünden, değişken modele dahil edilmemiştir. Benzer şekilde diyabet tedavisi alan bireylerde kan glukoz düzeyinin kontrol altına alınma durumunu öngören bir model oluşturmak amaciyla tek değişkenli analizlerde kan glukoz düzeyinin kontrol altına alınma durumuyla anlamlı ilişkisi bulunan yaş, eşlik eden kronik hastalık varlığı, literatürde kan glukoz düzeyinin kontrol altına alınma durumuyla ilişkili olduğu gösterilen cinsiyet, sosyal güvence varlığı, sigara içme durumu ve BKI değişkenlerinin alındığı geriye doğru eleme yöntemi ile lojistik regresyon modeli oluşturulmuştur. Çalışmada istatistiksel anlamlılık düzeyi $\mathrm{p}<0.05$ olarak alınmıștır. Veriler SPSS 15.0 istatistik paket programında değerlendirilmiştir.

\section{Bulgular}

Araştırma grubunun yaş ortalaması $60.78 \pm 10.68$ (En küçük:30, En büyük:92) yıldır, grubun \%63.4'ü kadın ve \%75.1'i evlidir. Grubun \%69.6'sı ilkokul ve altında 
öğrenim düzeyine sahiptir, \%80.3'ü kendi ekonomik durumunu orta olarak değerlendirmektedir ve \%94.6'sı herhangi bir sosyal güvenceye sahiptir. Araştırma grubunun \%20.5'i halen sigara içmektedir, eşlik eden kronik hastalığı olanlar grubun \%67.6'sını oluşturmaktadır. Araştırma grubunu oluşturan diyabetlilerin \%56.1'i obez ve \%44.9'u hipertansif olup, \%17.9'u yüksek LDL, \%12.8'i yüksek HDL ve \%27.9'u yüksek trigliserit düzeyine sahiptir (Tablo 1).

Tablo 1. Diyabetlilerde BKİ, kan basıncı, LDL, HDL ve trigliserit düzeylerinin dağılımı

\begin{tabular}{|c|c|c|c|}
\hline \multicolumn{2}{|c|}{ Değişkenler (N=1.643) } & \multirow[t]{2}{*}{$\mathbf{n}$} & \multirow[t]{2}{*}{$\%$} \\
\hline BKİ & $\mathrm{Kg} / \mathrm{m}^{2}$ & & \\
\hline Zayıf & $<18.50$ & 1 & 0.1 \\
\hline Normal & $18.50-24.99$ & 155 & 9.5 \\
\hline Fazla kilolu & $25.00-29.99$ & 563 & 34.3 \\
\hline $\begin{array}{l}\text { Kan basincl } \\
\text { Normal }\end{array}$ & $\begin{array}{l}\geq 30.00 \\
\mathrm{~mm} / \mathrm{Hg}\end{array}$ & 918 & 56.1 \\
\hline Sinırda & $<120 / 80$ & 241 & 14.7 \\
\hline $\begin{array}{l}\text { yüksek } \\
\text { Yüksek }\end{array}$ & $\begin{array}{l}120-139 / \\
80-89\end{array}$ & 664 & 40.4 \\
\hline & $\geq 140 / 90$ & 738 & 44.9 \\
\hline LDL & $\mathrm{mg} / \mathrm{dl}$ & & \\
\hline Normal & $\leq 129$ & 866 & 52.7 \\
\hline $\begin{array}{l}\text { Sinırda } \\
\text { yüksek }\end{array}$ & $130-159$ & 483 & 29.4 \\
\hline Yüksek & $\geq 160$ & 294 & 17.9 \\
\hline HDL & $\mathrm{mg} / \mathrm{dl}$ & & \\
\hline Düşük & $\leq 39$ & 479 & 29.1 \\
\hline Normal & $40-59$ & 954 & 58.1 \\
\hline Yüksek & $\geq 60$ & 210 & 12.8 \\
\hline $\begin{array}{l}\text { Trigli } \\
\text { serit }\end{array}$ & $\mathrm{mg} / \mathrm{dl}$ & & \\
\hline Normal & $\leq 149$ & 836 & 50.9 \\
\hline $\begin{array}{l}\text { Sinırda } \\
\text { yüksek }\end{array}$ & $150-199$ & 348 & 21.2 \\
\hline Yüksek & $\geq 200$ & 459 & 27.9 \\
\hline Toplam & & 1.643 & 100.0 \\
\hline
\end{tabular}

Araştırmada diyabetlilerin \%75.4'ü veri toplanan tarihlerde tedavi aldığını belirtmiştir. Tedavi alanların \%32.6'sında kan glukoz düzeyi, \%21.8'inde kan basincl, \%9.4'ünde BKİ, \%34.7'sinde LDL, \%45.2'sinde HDL, \%52.6'sinda trigliserit düzeyinin kontrol altında olduğu belirlenmiștir (Tablo 2).

Tablo 2. Diyabet tedavisi alan bireylerde kan glukoz, kan basıncı, BKİ, LDL, HDL, trigliserit düzeylerinin kontrol altına alınma durumu

\begin{tabular}{llcc}
\hline \multicolumn{2}{l}{ Değişkenler (N=1.238) } & $\mathbf{n}$ & $\mathbf{\%}$ \\
\hline Kan glukoz & $<110 \mathrm{mg} / \mathrm{dl}$ & 404 & 32.6 \\
düzeyi & $\geq 110 \mathrm{mg} / \mathrm{dl}$ & 834 & 67.4 \\
(AKȘ) & & & \\
Kan basıncl & $<130 / 80$ & 270 & 21.8 \\
(mm/Hg) & $\geq 130 / 80$ & 967 & 78.2 \\
$\mathrm{BKI}$ & $<25.00$ & 116 & 9.4 \\
$\left(\mathrm{~kg} / \mathrm{m}^{2}\right)$ & $\geq 25.00$ & 1.117 & 90.6 \\
$\mathrm{LDL}$ & $<100$ & 430 & 34.7 \\
$(\mathrm{mg} / \mathrm{dl})$ & $\geq 100$ & 808 & 65.3 \\
$\mathrm{HDL}$ & $\mathrm{E}: \leq 40, \mathrm{~K} \leq 50$ & 678 & 54.8 \\
(mg/dl) & $\mathrm{E}:>40, \mathrm{~K}:>50$ & 560 & 45.2 \\
Trigliserit & $<150$ & 651 & 52.6 \\
(mg/dl) & $\geq 150$ & 587 & 47.4 \\
Toplam & & 1.238 & 100.0 \\
\hline
\end{tabular}

${ }^{*}$ E: erkeklerde, K: kadınlarda HDL sınır değeri ifade etmektedir.

Tek değişkenli analizlerde diyabet tedavisi alma oranı 70 yaş ve üzeri bireylerde $(\mathrm{p}<0.001)$, kadınlarda $(\mathrm{p}=0.002)$, eşi ölmüş olanlarda $(\mathrm{p}=0.013)$, ilkokul ve altı öğrenim düzeyine sahip olanlarda $(\mathrm{p}<0.001)$, sosyal güvencesi olanlarda $(\mathrm{p}<0.001)$, sigara içmeyenlerde $(\mathrm{p}=0.010)$ ve eşlik eden kronik hastalığı olanlarda $(\mathrm{p}<0.001)$ istatistiksel olarak anlamlı düzeyde yüksektir (Tablo 3). 
Tablo 3. Diyabetlilerde bazı sosyodemografik özelliklere göre tedavi alma durumu

Değişkenler ( $\mathrm{N}=1.643)$

\section{Diyabet tedavisi} alma

\begin{tabular}{|c|c|c|c|c|c|}
\hline & & $\mathbf{n}$ & $\mathbf{n}$ & $\%$ & $\mathbf{p}^{*}$ \\
\hline \multirow[t]{3}{*}{ Yaş } & $30-44$ & 126 & 72 & 57.1 & \multirow{3}{*}{$<0.001$} \\
\hline & $45-69$ & 609 & 435 & 71.4 & \\
\hline & 70 ve üzeri & 907 & 731 & 80.6 & \\
\hline \multirow[t]{2}{*}{ Cinsiyet } & Kadın & 1.040 & 810 & 77.9 & \multirow{2}{*}{0.002} \\
\hline & Erkek & 602 & 428 & 71.1 & \\
\hline \multirow[t]{4}{*}{ Medeni durum } & Evli & 1.224 & 914 & 74.7 & \multirow{4}{*}{0.013} \\
\hline & Bekar & 44 & 27 & 61.4 & \\
\hline & Eşi ölmüş & 343 & 275 & 80.2 & \\
\hline & Boşanmış & 19 & 12 & 63.2 & \\
\hline \multirow[t]{3}{*}{ Öğrenim durumu } & İlkokul ve altı & 1.136 & 889 & 78.3 & \multirow{3}{*}{$<0.001$} \\
\hline & Ortaokul & 150 & 105 & 70.0 & \\
\hline & Lise ve üzeri & 346 & 238 & 68.8 & \\
\hline \multirow[t]{3}{*}{ Algllanan ekonomik durum } & İyi & 129 & 98 & 76.0 & \multirow{3}{*}{0.239} \\
\hline & Orta & 1.309 & 978 & 74.7 & \\
\hline & Kötü & 193 & 155 & 80.3 & \\
\hline \multirow[t]{2}{*}{ Sosyal güvence varlığı } & Var & 1.553 & 1.188 & 76.5 & \multirow{2}{*}{$<0.001$} \\
\hline & Yok & 89 & 50 & 56.2 & \\
\hline \multirow[t]{3}{*}{ Sigara içme durumu } & İçiyor & 337 & 233 & 69.1 & \multirow{3}{*}{0.010} \\
\hline & Bırakmış & 466 & 358 & 76.8 & \\
\hline & İçmiyor & 838 & 647 & 77.2 & \\
\hline \multirow[t]{2}{*}{ Eşlik eden kronik hastalık } & Var & 1.111 & 907 & 81.6 & \multirow{2}{*}{$<0.001$} \\
\hline & Yok & 531 & 331 & 62.3 & \\
\hline
\end{tabular}

*Ki kare testi.

Geriye doğru eleme yöntemi ile oluşturulan lojistik regresyon modeline göre diyabet tedavisi alma durumu 30-44 yaș grubuna klyasla 45-69 yaş grubunda 1.34 kat (\%95.0 GA: 1.03-1.74), 70 ve üzeri yaş grubunda 1.76 kat (\%95.0 GA: 1.14-2.72), sosyal güvenceye sahip olmayanlara göre olanlarda 2.21 kat (\%95.0 GA:1.39-3.52) yüksektir. Diyabet için tedavi alma durumu eşlik eden kronik hastalığ olanlarda olmayanlara göre 2.24 kat (\%95.0 GA: 1.742.89) yüksektir (Tablo 4). 
Tablo 4. Lojistik regresyon modelinde diyabet tedavisi alma durumuyla ilişkili değişkenler

\begin{tabular}{|c|c|c|c|c|c|}
\hline Değişkenler ( $\mathrm{N}=1.643$ ) & & B & SE & $\mathbf{p}$ & OR (\%95 GA) \\
\hline \multirow[t]{3}{*}{ Yaş } & $30-44$ & & & & 1.00 \\
\hline & $45-69$ & 0.293 & 0.133 & 0.027 & $1.34(1.03-1.74)$ \\
\hline & 70 ve üzeri & 0.565 & 0.221 & 0.011 & $1.76(1.14-2.72)$ \\
\hline \multirow[t]{2}{*}{ Cinsiyet } & Kadın & & & & 1.00 \\
\hline & Erkek & 0.190 & 0.141 & 0.179 & $1.21(0.92-1.59)$ \\
\hline \multirow[t]{3}{*}{ Öğrenim durumu } & Lise ve üzeri & & & & 1.00 \\
\hline & İlkokul ve altı & 0.045 & 0.221 & 0.840 & $0.96(0.62-1.47)$ \\
\hline & Ortaokul & 0.280 & 0.151 & 0.064 & $0.76(0.56-1.02)$ \\
\hline \multirow[t]{2}{*}{ Sosyal güvence } & Yok & & & & 1.00 \\
\hline & Var & 0.793 & 0.237 & 0.001 & $2.21(1.39-3.52)$ \\
\hline \multirow[t]{3}{*}{ Sigara içme durumu } & İçmiyor & & & & 1.00 \\
\hline & İçiyor & 0.019 & 0.161 & 0.905 & $1.02(0.74-1.39)$ \\
\hline & Bırakmış & 0.097 & 0.155 & 0.530 & $0.91(0.67-1.23)$ \\
\hline \multirow[t]{2}{*}{ Eşlik eden kronik hastalık } & Yok & & & & 1.00 \\
\hline & Var & 0.805 & 0.129 & 0.000 & $2.24(1.74-2.89)$ \\
\hline
\end{tabular}

ß: Regresyon katsayıSı, SE: Standart hata, OR: Odds Ratio, GA: \%95.0 güven aralığını ifade etmektedir. Hosmer and Lemeshow test: 0.935 Nagelkerke R square: 0.190.

Diyabet tedavisi alan bireylerde kan glukoz düzeyinin kontrol altına alınma oranı 30-44 yaș aralığında $(\mathrm{p}=0.011)$ ve eşlik eden kronik hastalığ olanlarda $\quad(\mathrm{p}=0.028)$ belirtilen değişkenlerin diğer kategorilerine göre istatistiksel olarak anlamlı düzeyde yüksektir (Tablo 5).

Geriye doğru eleme yöntemi ile oluşturulan lojistik regresyon modeline göre diyabet tedavisi alan bireylerde kan glukoz düzeyinin kontrol altına alınma durumu eşlik eden kronik hastalığı olanlarda olmayanlara göre 1.49 kat (\%95.0 GA:1.121.99) yüksektir (Tablo 6).

\section{Tartışma}

Araştırma grubunun yaklaşık \%25'i tedavi almamaktadır ve tedavi alanların ise sadece \%33'ünde kan glukoz düzeyi kontrol altındadır. Kan basıncı, BKİ, LDL, HDL ve trigliserit düzeylerinin de kontrol altına alınma durumu ise istenen düzeyde değildir.

$\mathrm{Bu}$ çalışmada diyabetlilerin yaklaşık \%75'inin tedavi aldığı belirlenmiştir. Çok uluslu ileriye yönelik bir çalışma olan ve toplumdaki diyabetlilerin günlük bakım ve yaşam alışkanlıklarını yansıtan IDMPS (International Diabetes Management Practices Study) çalışmasında hiç tedavi almayanların oranı yaklaşık \%25 olarak belirtilmektedir. ${ }^{15}$ 
Tablo 5. Diyabet tedavisi alan bireylerde kan glukoz düzeyinin kontrol altına alınma durumunun bazı sosyodemografik özelliklere göre dağılımı

\begin{tabular}{|c|c|c|c|c|c|}
\hline \multirow[t]{2}{*}{ Değişkenler (N=1.238) } & & \multicolumn{4}{|c|}{$\begin{array}{l}\text { Kan glukoz düzeyi } \\
\quad<110 \mathrm{mg} / \text { dl }\end{array}$} \\
\hline & & $\mathbf{n}$ & $\mathbf{n}$ & $\%$ & $\mathbf{p}^{*}$ \\
\hline \multirow[t]{3}{*}{ Yaş } & $30-44$ & 72 & 33 & 45.8 & \multirow{3}{*}{0.011} \\
\hline & $45-69$ & 435 & 125 & 28.7 & \\
\hline & 70 ve üzeri & 731 & 246 & 33.7 & \\
\hline \multirow[t]{2}{*}{ Cinsiyet } & Kadın & 810 & 271 & 33.5 & \multirow[b]{2}{*}{0.395} \\
\hline & Erkek & 428 & 133 & 31.1 & \\
\hline \multirow[t]{4}{*}{ Medeni durum } & Evli & 914 & 299 & 32.7 & \multirow{4}{*}{0.791} \\
\hline & Bekar & 27 & 7 & 25.9 & \\
\hline & Eşi ölmüş & 275 & 93 & 33.8 & \\
\hline & Boşanmış & 12 & 3 & 25.0 & \\
\hline \multirow[t]{3}{*}{ Öğrenim durumu } & İlkokul ve altı & 889 & 292 & 32.8 & \multirow{3}{*}{0.873} \\
\hline & Ortaokul & 105 & 32 & 30.5 & \\
\hline & Lise ve üzeri & 238 & 79 & 33.2 & \\
\hline \multirow[t]{3}{*}{ Algılanan ekonomik durum } & İyi & 98 & 34 & 34.7 & \multirow{3}{*}{0.557} \\
\hline & Orta & 978 & 323 & 33.0 & \\
\hline & Kötü & 155 & 45 & 29.0 & \\
\hline \multirow[t]{2}{*}{ Sosyal güvence } & Var & 1.188 & 390 & 32.8 & \multirow{2}{*}{0.476} \\
\hline & Yok & 50 & 14 & 28.0 & \\
\hline \multirow[t]{3}{*}{ Sigara içme durumu } & İçiyor & 233 & 76 & 32.6 & \multirow{3}{*}{0.545} \\
\hline & Bırakmış & 358 & 109 & 30.4 & \\
\hline & İçmiyor & 647 & 219 & 33.8 & \\
\hline \multirow[t]{2}{*}{ Eşlik eden kronik hastalık } & Var & 907 & 312 & 34.4 & \multirow{2}{*}{0.028} \\
\hline & Yok & 331 & 92 & 27.8 & \\
\hline \multirow{2}{*}{ BKI } & Zayıf-normal & 116 & 42 & 36.2 & \multirow{2}{*}{0.395} \\
\hline & Fazla kilolu-obez & 1117 & 361 & 32.3 & \\
\hline
\end{tabular}

*Ki kare testi. 
Tablo 6. Lojistik regresyon modelinde diyabet tedavisi alan bireylerde kan glukoz düzeyinin kontrol altına alınma durumuyla ilişkili değişkenler

\begin{tabular}{|c|c|c|c|c|c|}
\hline Değişkenler ( $\mathrm{N}=1.238$ ) & & B & SE & $\mathbf{p}$ & OR (\%95 GA) \\
\hline \multirow[t]{3}{*}{ Yaş } & 70 ve üzeri & & & & 1.0 \\
\hline & $30-44$ & 0.698 & 0.260 & 0.007 & $0.49(0.83-1.21)$ \\
\hline & $45-69$ & 0.175 & 0.134 & 0.189 & $1.19(0.92-1.55)$ \\
\hline \multirow[t]{2}{*}{ Cinsiyet } & Erkek & & & & 1.0 \\
\hline & Kadın & 0.042 & 0.144 & 0.771 & $0.96(0.72-1.27)$ \\
\hline \multirow[t]{2}{*}{ Sosyal güvence } & Yok & & & & 1.0 \\
\hline & Var & 0.269 & 0.324 & 0.414 & $0.77(0.41-1.45)$ \\
\hline \multirow[t]{3}{*}{ Sigara içme durumu } & İçiyor & & & & 1.0 \\
\hline & İçmiyor & 0.122 & 0.190 & 0.521 & $1.13(0.79-1.64)$ \\
\hline & Bırakmış & 0.030 & 0.172 & 0.863 & $0.97(0.69-1.36)$ \\
\hline \multirow[t]{2}{*}{ Eşlik eden kronik hastalık } & Yok & & & & 1.0 \\
\hline & Var & 0.401 & 0.149 & 0.007 & $1.49(1.12-1.99)$ \\
\hline \multirow[t]{2}{*}{ BKİ } & Fazla kilolu-obez & & & & 1.0 \\
\hline & Zayılf-normal & 0.251 & 0.209 & 0.231 & $0.78(0.52-1.17)$ \\
\hline
\end{tabular}

Hosmer and Lemeshow test: 0.940 Nagelkerke R square: 0.018 .

Toplum tabanlı çalışmanın bulguları bu çalışma ile uyumludur. Aralarında Türkiye'nin de bulunduğu seçilmiş 12 Avrupa ülkesinde 2009 yılında 50 yaş ve üzeri 7.641 kişinin katılımı ile gerçekleştirilen EURIKA çalışmasında da diyabetlilerin \%87.2'sinin tedavi aldı ̆̆ bildirilmektedir.13 Sözü geçen çalışmada tedavi alma oranının yüksek olması çalışmanın ileri yaş grubunda yürütülmüş olmasından kaynaklanabilir.

Türkiye'de diyabet tedavisi alma durumuna yönelik yapılan çalışmalar sınırlı sayıdadır. Yılmaz ve arkadaşları tarafından Dokuz Eylül Üniversitesi Tıp Fakültesi Endokrinoloji Polikliniğine başvuran 18 yaş ve üzeri 103 diyabetlinin katılımı ile yürütülen çalışmada oral antidiyabetik kullanımının erkeklerde \%61.7 kadınlarda
\%72.6, insülin kullanımının ise erkeklerde $\% 27.7, \quad$ kadınlarda $\% 15.1 \quad$ olduğu belirtilmektedir. ${ }^{11}$ Çıtıl ve arkadaşları tarafından Kayseri'de bir sağlık ocağına başvuran 30 yaş ve üzeri 294 diyabetlinin katılımı ile yürütülen bir başka çalışmada diyabetlilerin yaklaşık \%8'inin ilaç tedavisi almadığı, \%5'inin sadece diyet yaptığ bildirilmektedir. ${ }^{26}$ Sözü geçen çalışmalarda tedavi alma oranının bu çalışmadan yüksek olması çalışmaların sağlık kuruluşuna başvuran bireylerde yürütülmesinden kaynaklanabilir.

$\mathrm{Bu}$ çalışmada diyabetlilerde kan glukoz düzeyinin kontrol altına alınma oranı AKŞ değeri esas alınarak incelendiğinde yaklaşık \%33'tür. 2009 yılında yürütülen EURIKA çalışmasında tedavi alan diyabetlilerin yaklaşık \%20'sinde AKŞ'nin 
110mg/dl'nin altında olduğu bildirilmektedir. ${ }^{13}$ Çalışmada AKŞ düzeyine göre kan glukoz düzeyinin kontrol altına alınma oranının bu çalışmaya kıyasla düşük olması çalışmanın 50 yaş ve üzeri bireylerde gerçekleştirilmiş olmasindan kaynaklanabilir. ABD'de 1999-2008 yılları arasında tedavi alan 1.214 diyabetli ile yürütülen NHANES çalışmasında diyabetlilerin \%54.4'ünde LDL kolesterolün $100 \mathrm{mg} / \mathrm{dl}$ 'nin altında, erkeklerde HDL kolesterolün $40 \mathrm{mg} / \mathrm{dl}$, kadınlarda ise $50 \mathrm{mg} / \mathrm{dl}$ 'nin üzerinde olma oranının $\% 63.9$ ve $130 / 80 \mathrm{~mm} / \mathrm{Hg}$ ve altında kan basıncina sahip olanların oranının ise \%55.1 olduğu belirtilmektedir. ${ }^{27}$ Sözü geçen çalışmada kan basincl ve lipid kontrol düzeyleri bu çalışmaya göre yüksektir. Bunun nedeni olarak çalışmada diyabetli bireylerin yaklaşık \%60'ının antihipertansif, \%40'ının ise lipid düşürücü ilaç kullanmaları ya da çalışmanın bu çalışmaya göre daha genç bir grupta 20 yaş ve üzeri diyabetlilerde yürütülmüş olması düşünülebilir. İngiltere'de birinci basamak sağlık kuruluşuna kayıtlı 270 diyabetli ile yürütülen retrospektif çalışmada kan basıncı için sınır değer 135/85mm/Hg olarak kabul edilmiş ve diyabetlilerin yaklaşık \%65'inde kan basıncının kontrol altında olduğu bildirilmiştir. Aynı çalışmada kan glukoz düzeyi kontrolünün değerlendirilmesinde HbA1c tanı testi olarak kullanılmış ve diyabetlilerin yaklaşı \%36'sında HbA1c'nin \%7'nin, \%55'inde LDL kolesterolün $100 \mathrm{mg} / \mathrm{dl}$ nin, $\% 49^{\prime}$ unda trigliserit düzeyinin $150 \mathrm{mg} /$ dl'nin altında olduğu ve yaklaşık \%61'inde HDL kolesterolün $40 \mathrm{mg} / \mathrm{dl}$ 'nin üzerinde olduğu bildirilmiștir. ${ }^{17}$ Sözü geçen çalışmada kontrol oranları bu çalışmaya kıyasla yüksektir ve kan basıncı açısından bu yüksekliğin nedeni araştırma grubunu oluşturan diyabetlilerin \%95.0'ının antihipertansif tedavi alması olabilir. Ayrıca iki çalışmada lipid kontrol oranları arasındaki farklılık çalışmanın gelişmiş bir ülke olan İngiltere'de birinci basamak sağlık kuruluşunda izlenen bireylerde gerçekleştirilmiş olması ile açıklanabilir.

Türkiye'de diyabetlilerde kan glukoz düzeyi, BKİ, kan basıncı ve lipidlerin kontrolüne ilişkin çalışmalar sınırlı sayıdadır. 2010 yılında Satman ve arkadaşları tarafından ikincisi yapılan TURDEP II çalışmasında diyabetli bireylerin yaklaşık \%35'inde HbA1c'nin \%6.5'in altında olduğu belirtilmektedir. ${ }^{4}$ Yllmaz ve arkadaşları tarafından yürütülen çalışmada HbA1c değerinin erkeklerin \%34.6'sında, kadınların ise \%41.5'inde \%6.5'in altında olduğu bildirilmektedir. ${ }^{11}$ Oğuz ve arkadaşları tarafından 2008 yılında Türkiye genelinde 44 merkezde 2.358 diyabetlinin katılımı ile yürütülen çalışmada da diyabetlilerin yaklaşık \%36'sında HbA1c'nin \%7'nin altında olduğu belirtilmektedir. ${ }^{12}$ Çıtıl ve arkadaşları tarafından yürütülen çalışmada da diyabetlilerin yaklaşık \%25'inde hedeflenen glisemik değere (HbA1c <\%6.5) ulaşıldı̆g bildirilmektedir. ${ }^{26}$ Çalışmalarda kan glukoz düzeyi kontrolü için farklı tanı testleri ve sinır değerler kullanılmış olmasına karşın, kan glukoz düzeyi kontrolüne ilişkin bulguların uyumlu olduğu söylenebilir. Çukurova Üniversitesi Tıp Fakültesi Yalım Erez aile hekimliği polikliniğine Mart-Eylül 2007 tarihleri arasında başvuran, en az altı aylık diyabet tanısı olan ve tedavi edilen 112 birey üzerinde gerçekleştirilen çalışmada ise bireylerin \%40.2'sinde kan glukoz düzeyinin, $\% 20.5$ 'inde $\operatorname{kan}$ basincinın, \%32.1'inde LDL'nin, \%24.1'inde HDL'nin ve \%33.0'ünde trigliserit düzeyinin kontrol altında olduğu belirtilmektedir. Belirtilen çalışmada kan glukoz düzeyi AKŞ ve HbA1c ile değerlendirilmiş, buna göre araştırma grubunun \%32.1'inde HbA1c'nin \%7.0'in altında, \%40.2'sinde ise AKŞ'nin 70$130 \mathrm{mg} / \mathrm{dl}$ arasında olduğu bildirilmektedir. ${ }^{16}$ Birinci basamak sağlık kuruluşunda izlenen bireyler üzerinde yürütülen bu çalışmada AKŞ'ine göre kan glukoz düzeyi kontrol oranının bu çalışmaya kıyasla yüksek olması, çalışmada kriter alınan sınır değerlerin farklı olmasından ya da çalışmanın birinci basamak sağlık kuruluşunda izlenen bireylerde gerçekleştirilmesinden kaynaklanabilir. Benzer şekilde, Yılmaz ve arkadaşları ${ }^{11}$ tarafından yürütülen çalışmada da diyabetli erkeklerin \%97.9'unun, kadınların ise 
\%88.7'sinin kan basıncının 140/90 $\mathrm{mm} / \mathrm{Hg}^{\prime}$ nın altında olduğu bildirilmektedir. $\mathrm{Bu}$ çalışmaya göre görece yüksek olan kan basıncı kontrol oranı çalışmanın hastane polikliniğinde izlenen diyabetlileri kapsaması ile açılklanabilir.

$\mathrm{Bu}$ araştırmada diyabet için tedavi alma oranının yaş arttıkça $\operatorname{arttığ~}$ belirlenmiştir. Yaş kategorileri içerinde özellikle diyabetlilerin yaklașık \%55'ini oluşturan 70 yaş ve üzeri grupta tedavi alma oranının yüksek olması bu bireylerin yaklaşık \%64'ünde eşlik eden en az bir kronik hastalığın bulunmasından ve diyabetlerin bu nedenle sağlık hizmeti almak için daha çok başvuru yapmalarından kaynaklanıyor olabilir. Diyabet için tedavi alma oranı sosyal güvenceye sahip olan bireylerde daha yüksektir. Bu bulgu sağlık hizmetlerine erişimde eşitsizliğin bir göstergesi olarak yorumlanabilir. Sosyal güvenceye sahip olanlarda tedavi alma oranının yüksek olması grubun hizmet alımında ekonomik kaygı duymaması ve sağlık hizmetlerinden daha çok yararlanmaları ile açıklanabilir. Acemoğlu ve arkadaşları $^{28}$ tarafından Diyarbakır'da yürütülen çalışmada da benzer şekilde sosyal güvencesi olmayan diyabetlilerin yaklaşık yarısından fazlasının sağlık hizmeti almadığı belirtilmektedir. Eşlik eden kronik hastalığ olan bireylerin büyük çoğunluğu 70 ve üzeri yaş grubundadır. Eşlik eden kronik hastalığa sahip olan diyabetlilerde tedavi alma oranının yüksek olmasının nedeni hastalık sayısıyla paralel olarak artan yakınmaların ileri yaş grubunda daha sık ortaya çıkması nedeniyle bu bireylerin sağlik hizmetlerinden daha çok yararlanmaları olabilir. ${ }^{29}$ Diyabet tedavisi alan bireylerde eşlik eden kronik hastalığı olanlarda kan glukoz düzeyinin kontrol altına alınma oranı yüksektir. Eşlik eden kronik hastalığı olanlarda kan glukoz düzeyinin kontrol altına alınma oranının yüksek olması bu bireylerin birden fazla kronik hastalık nedeniyle sağlık hizmetlerinden daha çok yararlanmalarından kaynaklanabilir. Obezite diyabetli bireylerde kan glukoz düzeyi, kan basıncı ve kolesterol düzeylerinin kontrol altına alınmasının önüne geçen bir durumdur. ${ }^{10} \mathrm{Bu}$ araștırmada diyabet tedavisi alan bireylerde BKİ'nin kan glukoz düzeyinin kontrol altına alınma durumu ile ilişkili bulunmaması araştırma grubun yaklaşı \%91'inin fazla kilolu ya da obez olmasından kaynaklanabilir.

\section{Araştırmanın güçlü yanları ve kısıtlılıkları}

Görece büyük bir araştırma grubu üzerinde çalışmanın yürütülmesi ve ölçüm sonuçlarının değerlendirilmesinde karşılaştırılabilir kriterlerin kullanılması bu çalışmanın güçlü yanlarındandır. Öte yandan, çalışmada maliyeti nedeniyle uzun dönem glisemik kontrol düzeyini gösteren HbA1c'nin kan glukoz düzeyi kontrolünün değerlendirilmesinde kullanılamaması çalışmanın önemli kısıtlılıklarından biridir. Çalışmada tedavi alan diyabetlilerde kan basıncl ve lipid kontrol düzeylerinin değerlendirilmesinde antihipertansif ve lipid düşürücü ilaçların kullanılma durumunun dikkate alınmaması araștırmanın bir başka kısıtlılığıdır.

Dünya Sağlık Örgütü tarafından diyabet tedavisinin egzersizle kombine diyet tedavisi, oral hipoglisemik tedavi ve insülin tedavisinden oluşan üç bileşenden oluştuğu vurgulanmıştır. ${ }^{30} \mathrm{Bu}$ çalışmada yalnızca ilaç tedavisinin sorgulanması, egzersizle kombine diyet tedavisinin sorgulanmaması çalışmanın kısıtlılığıdır ve gruplar arası karşılaştırmalarda önemli bir karıştırıcı faktör olarak rol oynamış olabilir. Çalışmanın önemli kısitlılıklarından biri de diyabetiklerin sağlık hizmetini nereden ve ne şekilde aldıkları, ayrıca hastalıklarına ilişkin bilgi düzeylerinin sorgulanmamış olmasıdır.

\section{Sonuç ve Öneriler}

Balçova'da erişkin yaş grubundaki diyabetli her dört kişiden biri tedavi almamaktadır ve diyabetli her üç kişiden yalnızca birinin kan glukoz düzeyi kontrol altındadır. Diyabet komplikasyonları açısından değiștirilebilir risk faktörlerinin başında gelen sigara kullanımı diyabetlilerde halen yaygındır ve yaklaşık her iki 
diyabetliden biri obezdir. Benzer şekilde kan basıncı ve lipidlerin de kontrol altına alınma oranı istenen düzeyde değildir. Bu bulgular toplumda diyabetli bireylerde komplikasyon gelişiminin önlenmesine yönelik bilgi düzeyinin ve farkındalığın yeterli olmadığını, diyabetli bireylerin izlemlerinde ve bu bireylere sunulan hizmetlerde aksamalar olduğunu düşündürmektedir. $\mathrm{Bu}$ nedenle diyabetlilerde komplikasyon gelişiminin önlenmesi için bilgi düzeyinin ve farkındalığın arttırılmasına yönelik girişimler planlanmalı, diyabetlilerin tedavisinde en önemli ayaklardan biri olan izlemlerin yeterli ve düzenli bir biçimde yapılması sağlanmalı ve birinci basamak sağlık kuruluşları diyabet ve diğer bulaşıcı olmayan hastalıkların kontrolü açısından güçlendirilmelidir.

\section{Teşekkür}

Sunulan araştırma Dokuz Eylül Üniversitesi Bilimsel Araştırma Projeleri ve Balçova Belediyesi tarafından desteklenmiştir (Proje no: 2007161).

Ayrıca araştırma 2-6 Ekim 2012 tarihinde düzenlenen 15. Ulusal Halk Sağlığı Kongresinde sözlü bildiri olarak sunulmuştur.

\section{Kaynaklar}

1. T.C. Sağlık Bakanlı̆̆ı. Türkiye Diyabet Önleme ve Kontrol Programı Eylem Planı (2011-2014). Ankara: Anıl Matbaası, 2011.

2. International Diabetes Federation. IDF Diabetes Atlas, 6th ed. Brussels: IDF Publication, 2013.

3. Satman I, Yilmaz T, Sengül A, et al. Population-based Study of Diabetes and Risk Characteristics in Turkey: Results of the Turkish Diabetes Epidemiology Study (TURDEP). Diabetes Care 2002;25(9):1551-1556.

4. Satman I, Omer B, Tutuncu Y, et al. Twelve-year trends in the prevalence and risk factors of diabetes and prediabetes in Turkish adults. Eur J Epidemiol 2013;28(2):169-180.

5. Wee HL, Ho HK, Li SC. Public awareness of diabetes mellitus in Singapore. Singapore Med J 2002;43(3):128-134.

6. Buijsse B, Simmons RK, Griffin SJ, Schulze MB. Risk assessment tools for identifying individuals at risk of developing type 2 diabetes. Epidemiol Rev 2011;33(1):4662.

7. New Zealand Guidelines Group. Assessment and Management of Cardiovascular Risk. Wellington: New Zealand Guidelines Group, 2003.

8. World Health Organization. Guidelines for The Prevention, Management And Care of Diabetes Mellitus. WHO Regional Office for the Eastern Mediterranean: EMRO Technical Publication Series, No. 32; 2006.

9. American Diabetes Association. Standards of Medical Care for Patients with Diabetes Mellitus. Diabetes Care 2002;25(1):33-49.

10. Kamath A, Shivaprakash G, Adhikari P. Body mass index and waist circumference in Type 2 Diabetes mellitus patients attending a diabetes clinic. Int J Biol Med Res 2011;2(3):636-638.

11. Yılmaz S, Çömlekçi A, Ünal B. Bir endokrinoloji polikliniğinde izlenen tip 2 diyabet hastalarında tıbbi ve davranışsal tedavi yaklaşımlarının etkileri. STED 2013;22(6):220-225.

12. Oguz A, Gedik 0 , Hatemi $\mathrm{H}$, et al. Glycemic control of Turkish adult diabetic patients. Turk J Endocrinol Metab 2008;12(2):50-54.

13. Banegas JR, Lopez-Garcia E, Dallongeville J, et al. Achievement of treatment goals for primary prevention of cardiovascular disease in clinical practice across Europe: the EURIKA study. Eur Heart J 2011;32(17):2143-2152.

14. Satman I, Imamoglu S, Yilmaz C \& ADMIRE Study Group. A patient-based 
study on the adherence of physicians to guidelines for the management of type 2 diabetes in Turkey. Diabetes Research and Clinical Practice 2012;98:75-82.

15. İlkova $H$, Damcl $T$, Karşıdağ $K$ ve IDMPS Türkiye Çalıșma Grubu. Türkiye'de uluslararası diyabet tedavi pratiği gözlem çalıșması. Türkiye Verileri, 2006.

16. Tahmişçioğlu G. Birinci basamak sağlık kuruluşunda takip edilen tip 2 diabetes mellituslu hastaların glisemik kontrollerinin, lipid profillerinin ve yaşam kalitelerinin değerlendirilmesi. Yayınlanmamış Uzmanlık Tezi. Adana: Çukurova Üniversitesi, 2008.

17. Choe HM, Townsend KA, Blount G, Lo $\mathrm{CH}$, Sadowski L, Standford C. Treatment and control of blood pressure in patients with diabetes mellitus. Am J Health-Syst Pharm 2007;64(1):97-103.

18. Ergor G, Soysal A, Sozmen K, et al. Balcova heart study: Rationale and methodology of the Turkish cohort. Int J Public Health 2012;57(3):535-542.

19. American Diabetes Association. Standards of medical care in diabetes2011. Diabetes Care 2011;34(1):11-61.

20. International Diabetes Federation. IDF Clinical Guidelines Task Force. Global Guideline for Type 2 Diabetes. Brussels: IDF Publication, 2005.

21. World Health Organization. Report of a WHO Consultation on Obesity. Geneva: WHO Press, 1997.

22. Chobanian AV, Bakris GL, Black HR, et al. The Seventh Report of the Joint National Committee on Prevention, Detection, Evaluation, and Treatment of High Blood Pressure. The JNC 7 Report. JAMA 2003;289(19):2560-2572.

23. American Diabetes Association. Standards of medical care in diabetes2012. Diabetes Care 2012;35(1):11-63.

24. Third Report of National Cholesterol Education Program (NCEP) Expert Panel on Detection, Evaluation and Treatment of High Blood Cholesterol in Adults, Final Report. Circulation, 2002 [Online]. Erişim adresi: http://passthrough.fwnotify.net/download/506224/http://circ. ahajournals.org/content/106/25/3143.fu ll.pdf. Erişim tarihi: 7, 2015.

25. American Diabetes Association. Standards of medical care in diabetes2012. Diabetes Care 2012;35(1):4-10.

26. Çıtıl R, Öztürk Y, Günay O. Kayseri il merkezinde bir sağlık ocağına başvuran diyabetik hastalarda metabolik kontrol durumu ve eşlik eden faktörler. Erciyes Med J 2010;32(2):111-122.

27. Kuznik A, Mardekian J. Trends in utilization of lipid-and blood pressurelowering agents and goal attainment among the U.S. diabetic population, 19992008. Cardiovasc Diabetol 2011. doi:10.1186/1475-2840-10-31.

28. Acemoğlu $H$, Ertem $M$, Bahçeci $M$, Tuzcu A. Tip 2 diyabetes mellituslu hastaların sağllk hizmetlerinden yararlanma düzeyleri. EAJM 2006;38:8995 [Online]. Erişim adresi: http://www.eajm.org/sayilar/170/buyuk /pdf_EAJM_232.pdf. Erişim tarihi: April 7, 2015.

29. Beger T, Erdincler DS, Curgunlu A. Yaşlıda Diabetes Mellitus. Akad Geriatri 2009; 1: 20-30 [Online]. Erişim adresi: http://www.akadgeriatri.org/managete/f u folder/2009-01/html/2009-1-1-020030.htm. Erişim tarihi: April 7, 2015.

30. World Health Organization. Management of Diabetes Mellitus Standards of Care and Clinical Practice Guidelines. Alexandria, Egypt: WHO Regional Office for the Eastern Mediterranean, 1994. 